\title{
Research on Ideas and Countermeasures of Real Estate Economic Development under the New Regulation
}

\author{
Shuxian Deng ${ }^{1, a}$ and Xizhuan Shi, ${ }^{1}{ }^{*}$ \\ ${ }^{1}$ Information engineering college, Department of mathematics and physics, Huanghe Science and \\ Technology Colledge, Zhengzhou, P. R. China \\ adshuxian@163.com, b857931663@qq.com \\ ${ }^{*}$ The corresponding author
}

Keywords: Regulation; Real estate; Countermeasure; Forecast

\begin{abstract}
The downward pressure on the economy is growing recently. The pressure on real estate to inventory is also growing. Although the property market clinches a deal well, the majority of real estate enterprises still have greater selling pressure, so many real estate enterprises began to adjust company structure, merging regional companies and cut income level of management. Based on the change of the industry situation, many previously tight talents, including part of the talent back from the field, a large number of them unemployed at home, some of them also did not find their own position for up to six months. Even if to look for a job once more, the requirements to the enterprise brand and salary are also very reasonable. Under the pressure of economic downturn, we analyzed the present situation of the modern real estate enterprises, and pointed out the way out.
\end{abstract}

\section{Perspective for the Real Estate Enterprise Senior Management Personnel Leaving in 2016}

The downward pressure on the economy is growing recently. the pressure on real estate to inventory is also growing. Although the property market clinches a deal well, the majority of real estate enterprises still have greater selling pressure, so many real estate enterprises began to adjust company structure, merging regional companies and cut income level of management. Based on the change of the industry situation, many previously tight talents, including part of the talent back from the field, a large number of them unemployed at home, some of them also did not find their own position for up to six months. Even if to look for a job once more, the requirements to the enterprise brand and salary are also very reasonable.

All Kinds of Living Situation of the Real Estate Business Executives After Leaving Their Original Work. A lot of truth Contains in the nature, watching endless miles of rugged mountains and rivers, In fact just like the stock market's chart, no matter investment or in life, there are ups and downs, But that doesn't mean that is low in my present state, in other words, I'm also enjoying life now. Every Monday, I will be open the market at nine o 'clock on time, killing in the tide of the stock market. In the afternoon, I take the time to listen to lectures, watch the news and still enjoy a lot of entertainment every day. This is Mr. LI's living condition. Fight every day at the first line, so tired, I always think about to go back to have a rest, and I have had a rest for a year and a half. But I did not idle, I often eat and chat together with my friends, now I still very understand companies in a variety of dynamic.

As for the whereabouts of executives after leaving, most people claim that they have a rest first, and they should do work intra-industry in the future.

Mr. Zhao, Clearly can eat depend on the strength of his own, start the gym business, after leaving the real estate for a period of time, to have a good plan is needed at 60 years old, otherwise, all are late. Once have the right opportunity, they will return to the real estate circle but does not affect their current status, and this is another kind of experience." 
No matter how to look at executives' announcement, leaving reason is "personal reasons", rather than poor performance have led to the resignation. From the current understanding of the actual situation, the executives of resignation are still mostly work in the real estate circle.

Directors of Real Estate Enterprises Human Resources Fall into a Dilemma. This year, the directors of human resources are, in fact, into a dilemma, on the one hand, we hope that our company's CEOs can leave; on the other hand, we are difficult to recruit personnel. Due to the enterprises have to expand demand this year, we are looking for the right executives if successfully find a good one; it will have a lot of ascension to the company's senior management team construction. This is the status of a real estate enterprise.

The enterprise progress, however, did not go well. Although they may have to raise the joining treatment, they still can't find any positive reply from the right person. Generally, the company receives a large number of resumes at the end of every year, but this year, the CV has obviously increased. Judging from this year, candidates who have 6-10 years work experience significantly increased, most have enterprise management experience, many candidates have said that they can accept pay $10 \%$ drop [1].

Real Estate Companies Employing More Selective. Since the beginning of 2016, the demand of real estate enterprise's recruitment has an obvious decreasing trend, the new position and alternative number decreased by $30 \%$ compared with the same period in 2014. At the same time, many enterprises began downsizing. In December, some big companies began layoffs, an enterprise because of strategic adjustment, stop the expansion, is expected to cut 30\%; And the other enterprises because of strategic adjustment and capital chain tension, is expected to cut 40\% 40\% [2]; What's more, a well-known real estate enterprise due to the strategic center of gravity shifted to Shanghai, contraction projects, is expected to cut $70 \%$

Combining with the real estate executive headhunting market position data, A headhunting company deputy general manager Mr. GAO provides very valuable information for us: Job demand in 2015, is very different from previous years, Companies are very picky of choose and employ persons, no matter from the first record of formal schooling, work experience, or from the professional attitude, ability to work will make a comprehensive evaluation.

And local large and medium-sized real estate enterprises, because obviously felt the foreign real estate tycoons carve-up of their market share and influence, have to improve product quality, to expand their land reserves as the center of gravity of the enterprise development. In order to better survive in the competition of environment and development, they begin to pay close attention to the talent quality, from the enterprise executive recruitment area can be seen, for the enterprise President, vice President positions of talent acquisition, they have the vision to expand to the whole country and even abroad, Most of their executives are from the outside province which are well-known listed real estate companies, they have a progressive management concepts and standardize the management way. Request for the product positioning and quality is higher and higher, and hire those executives will improve enterprise product quality and competitiveness; reduce the gap from foreign enterprises, to win the market and customers.

Some of the enterprises, their demand change of choose and employ persons are maximum, their property and landscape position, such as work experience requirements for talents, not content to domestic, but towards the internationalization. For the small enterprises in the local, their living environment is more and worse: the economic situation deteriorates, stationed in foreign enterprises, bank loans contraction, capital chain tight, the stagnation of project contracting, their life will be sadder. For a new project, there is rigid demand for talent; for the project under construction, personnel changes are very small, post changes will be more.

\section{Real Estate Executives' Job-Hopping Becomes Fashion}

There are words which are called "Real estate enterprises like nails, soldiers in it like flowing water" in Real estate circle, said is the real estate industry reshuffle is too big! 
Since the beginning of 2015, it has been reported continuously by the media that a large number of real estate executives resign. In the market environment of Downward in the industry, profits shrinking, the real estate enterprises are facing the embarrassing situation firing and fired, and this situation is intensifying.

Why Real Estate Executives Concentrate Flees? In 2016, because of a number of good policy support and pulling, and improve product supply and demand docking success, there were signs of recovery in the property market. But this didn't seem to make the enterprise executives departure tide recedes. As of the first half of 2015, the key enterprise's high-level personnel resignation number was more than 2013 throughout the year. Although everyone's resignation reasons are not identical, inevitably, in the back of a good position, the real estate market decline has brought the huge impact, performance appraisal pressure, wages have plunged.

Inventory pressure, forcing companies to adjust development strategy, definitely force the enterprises to adjust human resource strategic planning, At this time, contradictions and problems will be more exposed, and become big background elements leading to professional manager resigned.

Personal Choices Under the Strategic Adjustment. There are some typical practical examples show personal choices of some executives: senior vice President and chief executive, MoJun, Vanke group, apply for early retirement On September 10, 2016[3]; chairman of the board of directors, deputy general manager Zheng Zhougang, the financial street in Guangzhou real estate co., LTD., apply resigned as deputy general manager duties for personal reasons On September 18, 2015. It is said that the resignation of Zheng Zhougang has a relationship with performance pressure, and so on. In addition, there are a lot of leader level characters on the departure list.

Marketing is resignation high-risk areas. Such as ShiMao Group vice President of marketing Xue-mei CAI, R\&F vice President of marketing Wen Gan etc. The real estate industry, from the relatively large change in the former chief executive to the fierce competition in the marketing director, and now seems to be the most stable positions are beginning to change, since Last year, the real estate senior professional managers all-round resignation has become a new trend.

Is Forced or Active, So Many Executives Leave? Whether it is the company's caliber or personal tone, the majority of these people's departure is personal reasons. Some people think that in addition to silver era irreversibly led to declining in margins, executives are difficult to achieve a goal, the country's top-down anti-corruption wind blow into the enterprise interior is also an important factor. It is reported, according to the real estate enterprise internal operation management mechanism, the vast majority of companies are at the beginning of this year and senior executives and sign the annual target responsibility of the company, and implement quarterly and semi-annual evaluation. Almost hopeless to complete on the target case, under pressure to resign, or enterprise shall be ordered to resign, is a natural thing to do.

For executives' leaving, you can use a keyword to describe, that is, self-willed. Behind the phenomenon of leaving the phenomenon, not a simple professional salary system or promotion system can be explained; the key lies in the traditional organizational structure of a self-break. By leaving, they are able to expand the new business, planning a new career, and to establish a new goal and direction, to achieve my future I call the shots. Executive's entrepreneurship, on the one hand, with a good understanding of the original real estate industry, and then the development of some new business has a keen observation. On the other hand, they are able to rely on existing social resources, so as to grow rapidly in the entrepreneurial project.

\section{Where Will the Enterprise Executives Go After Leaving Their Office?}

(1) Job hopping in the industry. The most common are to hire the opposite executives each other.

(2) Retired after a successful career. Having experienced several changes in the industry, the industry executives retired after a successful career.

(3) To do one's own BOSS, start a new business. Some executives do their own boss, to start a new career after leaving the original company.

(4) Seize the "Internet +".Some executives set up real estate Internet service platform after leaving the company and engaged in real estate Internet financial business. 


\section{The Enterprise Will Reduce the Salary Standard, Real-Estate Executive Should Go Where In 2017?}

It can be seen from 2016 real estate remuneration report, the real estate industry is facing the huge pressure of competition, a lot of enterprises have experienced layoffs and pay cuts. Compared with the previous two years, in 2015 the salary increase is smaller; the overall increase is showing a trend of decline. Only about $30 \%$ of the population is on the rise. More than half remained stable and $11 \%$ of the population are being cut. And the pay gap is further amplified. the salary standards will be reduced in 2017, corporate assessment is also more stringent.

Real Estate Enterprises Gradually Compressed Talent Costs. From the beginning of last year, the salaries of the real estate industry generally appear greatly reduced; although the real estate market situation is becoming warm this year, due to the industry profit margins continue to decline, real estate enterprises have begun to compression management costs, gradually reduce the wages of senior. In 2016, it will be even harder.

Now the real estate industry has become a low-profit industry, salary levels are bound to change, and now the company employees have also been aware of this, so the senior management of the superior sense has been weakened. Professional manager's salary assessment mainly depends on the completion of the task, project quality and team management and so on. Since nearly two years of sales are not ideal, so the entire salary standard has been reduced, business assessment is also more stringent.

The Pay Cut Has Become The Industry Consensus When the Real Estate Business Profits Declined. With the declining of real estate investment, it has also lost its competitiveness in the past as a traditional industry. Lower pay is the industry consensus. A report shows that the average salary of real estate enterprises fell $1.8 \%$ in 2015[2].

As of October 30, 2015, due to "resign" and "personal reasons", the number leaving the company in the mainland executives of listed enterprise has reached 109 persons[5], during 2012 and 2014, the number of departure were 95, 89 and 154 respectively in the monitoring data summary[6] , it has presented a rising trend. on the one hand, Enterprise executives know the direction of the industry compared to the others, on the other hand, their career stability index is also an indicator whether the real estate industry is booming or not. An industry insider said that many enterprise executives realize this fluctuation in the market unlike the previous downturn, the behind deep reason is that the previous traditional real estate development mode is peaking. They can no longer rely on buying land, financing, selling the house to seek development. Whether it is commercial real estate, diversified development, or embraces the Internet, real estate business transformation is still in the exploratory stage, and the speed and effectiveness of the transition is also a gap between the individual expectations. In the future, the rigid demand people will reduce, it is bound to cause the loss of demand, and Combined with the more and more supply, traditional real estate enterprises' profit space will be more and smaller.

In the Face of Industry Adjustment, Job Hopping Should Be More Cautious. As the enterprise investment growth is slowing in recent years, some new real estate projects gradually reduce, and the number of jobs often associated with the project, it directly led to the demand for jobs. A human resources expert analyzed the situation from both demand and supply, In terms of supply, the real estate development process has accumulated a part of the employees, and coupled with the continuous graduate of college students, there are still a lot of talented people go into the industry. Overall, the talent supply is greater than the talent demand in the real estate human resources market.

The job-hopping reason of Job seekers can be roughly divided into the following categories: think of the future prospect, salary space, on the company's identity or not, among them, there are some people choose to leave, but they did not do rational analysis on the original enterprises. The job seekers reasonable job-hopping period is generally 3-5 years [6], the resume that has frequent job hopping are often seen as an inferior quality resume. Such people are often reluctant to do 
self-reflection, they are used to do job-hopping to solve the problem, The company will be more cautious about this kind of job seekers who have been taking problems of job hopping.

Under the Condition of the Real Estate New Situation, Real Estate Executives Where to Go? The real estate new situation let the real estate managers who have gotten lost become more confused. Recruitment market demand changes, it determines the whereabouts of the talent. For real estate managers in the current situation, they have the following directions to choose:

Seek Far and Neglect What Lies Close at Hand. Willing to be sent to work in the field, or go directly to a larger city to look for development opportunities. It is a bet and risk-taking behavior to the field to look for opportunities to develop, although just like sailing against the current, it may also be a different choice for the people who have really the ability and confidence.

Adjust Mentality. If the current business can be normal operation, and ensure the normal pay, this is a very lucky thing. One should cherish the opportunity to play oneself role, with a grateful attitude to return the enterprise, and to create a win-win situation.

Adjust Positioning. If there is no better development opportunity in the local area, consider the development of other regions. Although the inventory pressure is big in some places, there is still a certain development opportunity, relative to the vanity and pride, survival is always the absolute truth.

Career Transition. Combined with one's own core strengths, one can properly transform, and transform to derivatives of the real estate industry chain direction. For example construction, landscaping, property services, community health care, food and beverage services and other industries, and can Also transform to the Internet, education, consulting, financial services and other fields. For general-purpose talent, even if cross-industry, one can transform smoothly as long as his adaptive ability is strong, but this will mean to give up the past for professional and technical personnel, and start again, the risk of transformation will be great.

To Start Their Own Business. If you want to challenge your own life, try a new work and lifestyle, the professional managers can be trying to start a business or partnership with others to do pioneering work, you can make use of an existing network of contacts and resources to determine the direction of industry, product positioning and profit model. Although the State encourages National entrepreneurship and innovation, not all people are suitable for business, the success rate of entrepreneurship is, in fact, less than $5 \%$, and entrepreneurship is a kind of life experience.

\section{Analysis to the China's Urban Real Estate Market Development Trend}

We take use of life cycle hypothesis of macro consumption function, it has shown that consumers' consumption psychology, legal system at present and our country real estate market is not mature. This is the cause of downward pressure of the real estate market.

Insufficient consumption is an important conditionality factor for the sustainable development of China's economy. It is very difficult to maintain China's economic growth just depending on investment and export situation for a long time, the growth will face to adjustment inevitably in the coming years. Such adjustments will have a negative impact on the rapid development of China's economy, the impact degree depends entirely on consumer spending. Then, if the consume can't grow up to be instead of investment and export growth pillar, it is difficult to rule out the possibility of a hard landing.

Stimulating consumption growth is the fundamental of rapid economic development, and it is also the key to realize the economic growth mode transformation. The Economic pull is essential, therefore, comprehensive analysis of the real estate market should be strengthened. The purpose is to provide theoretical guidance for the correct macro-control policies for the government, To promote the healthy development of real estate industry and national economy in our country. So as to promote rapid development of our country's economy and real estate[4-7].

Model Design and Data Selection. We construct the following model:

$$
\ln P C_{m \tau}=\rho_{0}+\rho_{1} \ln H P I_{m \tau}+\rho_{2} \ln P A_{m \tau}+u_{m \tau}
$$




$$
\begin{aligned}
& \ln H P_{m \tau}=\sigma_{0}+\sigma_{1} \ln A P_{m \tau}+\sigma_{2} \ln I A G_{m \tau}+\sigma_{3} \ln I R P_{m \tau}+\sigma_{4} \ln B U C_{m \tau}+\lambda_{m \tau} \\
& \ln I C_{m \tau}=\omega_{0}+\omega_{1} \ln D H P_{m \tau}+\omega_{2} \ln R P_{m \tau}+\omega_{3} \ln R D P_{m \tau}+\zeta_{m \tau}
\end{aligned}
$$

Representing the urban residents per capita consumption expenditure, commodity house average price, per capita income, the income gap, the credit amount and rate of urbanization respectively[6-9].

The following results can get through some calculation [8-10].

Table 1 the statistical results

\begin{tabular}{|c|c|c|c|c|c|}
\hline number & Observed value & mean & standard error & Level & critical value \\
\hline 1 & 128 & 7.8246 & 0.1578 & -3.020686 & -3.65844 \\
\hline 2 & 235 & 8.3382 & 0.3643 & -2.799767 & -3.02068 \\
\hline 3 & 312 & 7.2243 & 0.3359 & -3.171457 & -3.64496 \\
\hline 4 & 207 & 8.7798 & 1.0754 & -0.729459 & -2.403331 \\
\hline 5 & 173 & 7.9403 & 0.3962 & -1.448802 & -3.64496 \\
\hline 6 & 195 & 9.1670 & 0.4616 & -3.234919 & -3.05216 \\
\hline
\end{tabular}

It can be seen from table 1 that the measurement results are ideal. Regression results show that the development of the real estate market has become increasingly difficult under the condition of the economic downward pressure is very obvious.

\section{Conclusions}

The empirical analysis results show that the real estate market development trend is negative value at present. Specifically, there are mainly the following reasons:(1) The real estate market development is not sound, the real estate market liquidity and variation trend of prices are not standard. (2) Compared with the western mature market countries, China's real estate market downward pressure is very big. (3) Most of the local residents purchase behavior is not an investment behavior.

As mentioned above, due to the Chinese consumers' consumption psychology, legal system and the present stage, our real estate market is not mature, there is still a large gap compared with developed countries. Therefore, we should constantly improve and standardize the real estate market to enhance consumer confidence. Make the real estate market gradually become an important channel of employment, and really play an important role in the market economy, so as to drive economic to grow and increase employment.

\section{Acknowledgements}

This work was supported by the Ph.D. Foundation of Henan University of Engineering (No. D2010012).

\section{References}

[1] Zhang Jinyan. Analysis of the influence factors of real estate economic fluctuation and Countermeasures. Chinese and foreign entrepreneurs.2016 (03).

[2] Liang Yanjun. The role of business administration in promoting the economic development of real estate. China collective economy. 2016 (03).

[3] Peng Yong, Sheng Baozhu. China's real estate economy sustainable development. Journal of Hubei University of Economics. 2016 (01).

[4] Li Xiaosong. Research on the coordinated development of real estate economy and market economy research. productivity. 2015 (12). 
[5] Zhao Min. Analysis of China's real estate economic development status and development trend of the era of finance. 2015(36).

[6] Matlack J L, Vigdor J L. Do Rising Tides Lift All Prices? Income Inequality and Housing Affordability, NBER Working Papers, 2016, No.12331.

[7] Quigley, J M, Raphael, S, and Smolensky, E. Homeless In America, Homeless In California, The Review of Economics and Statistics, 2015, 83:37-51.

[8] Jinyan Yi, Xueli Huang. Linear regression based on chaotic time series prediction model of supply chain performance evaluation. Statistics and decision, 2015, (22): p. 44(In Chinese).

[9] Fei Wang. Evaluation of bayesian vector autoregressive model to predict the performance of regional economy. Science and technology of China BBS, 2014, (10), p,138-143(In Chinese).

[10] Junyan jin, Chen jin. The weighted Markov chain in the application of real estate investment payback period prediction. Journal of hunan university of science and technology, 2016, (02),p, 63-66(In Chinese). 